\title{
Evidence-Based Evaluation of Biological Treatment in Crohn's Disease
}

\author{
Shiyao Chen and Yuan Zhao \\ Department of Gastroenterology, Zhongshan Hospital, Fudan University \\ P.R. China
}

\section{Introduction}

Crohn's disease (CD) is a chronic disorder of the gastrointestinal tract, which was characterized by a relapsing-remitting course with trans-mural inflammation of potentially any section of the digestive tract, leading to various intestinal and extra-intestinal manifestations. Although the etiology is currently unknown, inflammation, immunity, genetic and environmental factors have been suggested to predispose to CD.

The precise etiology of $\mathrm{CD}$ is not yet elucidated but the mucosal system is the central effector of intestinal inflammation and injury (Fig 1). The dysregulated mucosal immunity of the bowel is contributed by varied factors among which cytokines play a central role in modulating inflammation. Others are gut associated lymphoid tissues (GALT), pathogen recognition receptors (PRRS), professional antigen presenting cells (APCs), epithelial cells of gut and resident microflora, etc.

\subsection{Cytokines}

There are two types of cytokines: anti-inflammatory cytokines (IL-10, IL-11, etc) and proinflammatory cytokines (IL-1, IL-2, IFN $\gamma, \mathrm{TNFa}, \mathrm{IL}-12, \mathrm{IL}-18$, etc). The anti-inflammatory cytokines have some beneficial effects in CD. IL-10 is produced by Th2 cells and suppresses the production of IL-2 and IFNY by Th1 cells. Evidences showed that IL-10 and IL-11 might be therapeutic agents in CD. IL-10 knockout mice develop severe transmural and granulomatous inflammation of the small and large bowel, reminiscent of $C D$, and the inflammation can be prevented by the administration of IL-10. IL-11 is derived from mesenchymal cells. Studies showed that IL-11 could attenuate the inflammatory response and enhance the integrity of the intestinal mucosa. Among the proinflammatory cytokines, TNFa is the most important and widely investigated factor. TNFa is secreted into intestinal mucosa by macrophages and monocytes and is bound to $\mathrm{T}$ lymphocytes and monocytes. Its biological activity is mediated by cell surface TNFa receptors binding to either membranebound or soluble TNFa. TNFa may increase adhesion molecules, allowing for increased cell infiltration and enhanced metalloproteinase and collagenase production, which help form ulcers and fistulas. It can also mediate recruitment of leukocytes from blood vessels into intestinal mucosa through circulating cells interacting with adhesion molecules on the vascular endothelium. TNFa also activates increases the production of IFN $\gamma$ by mucosal $\mathrm{T}$ cells independently of IL-12 and IL-18. It activates CD44 in T cells and enhances 
intraepithelial lymphocyte proliferation and migration. Multiple antibodies to TNFa have proven effective in both induction and maintenance of remission for CD. TNFa appears to be a determinant in granuloma formation, and, together with IL-6, IL-1 may contribute to the constitutional symptoms of IBD and lead to the generation of acute-phase proteins.

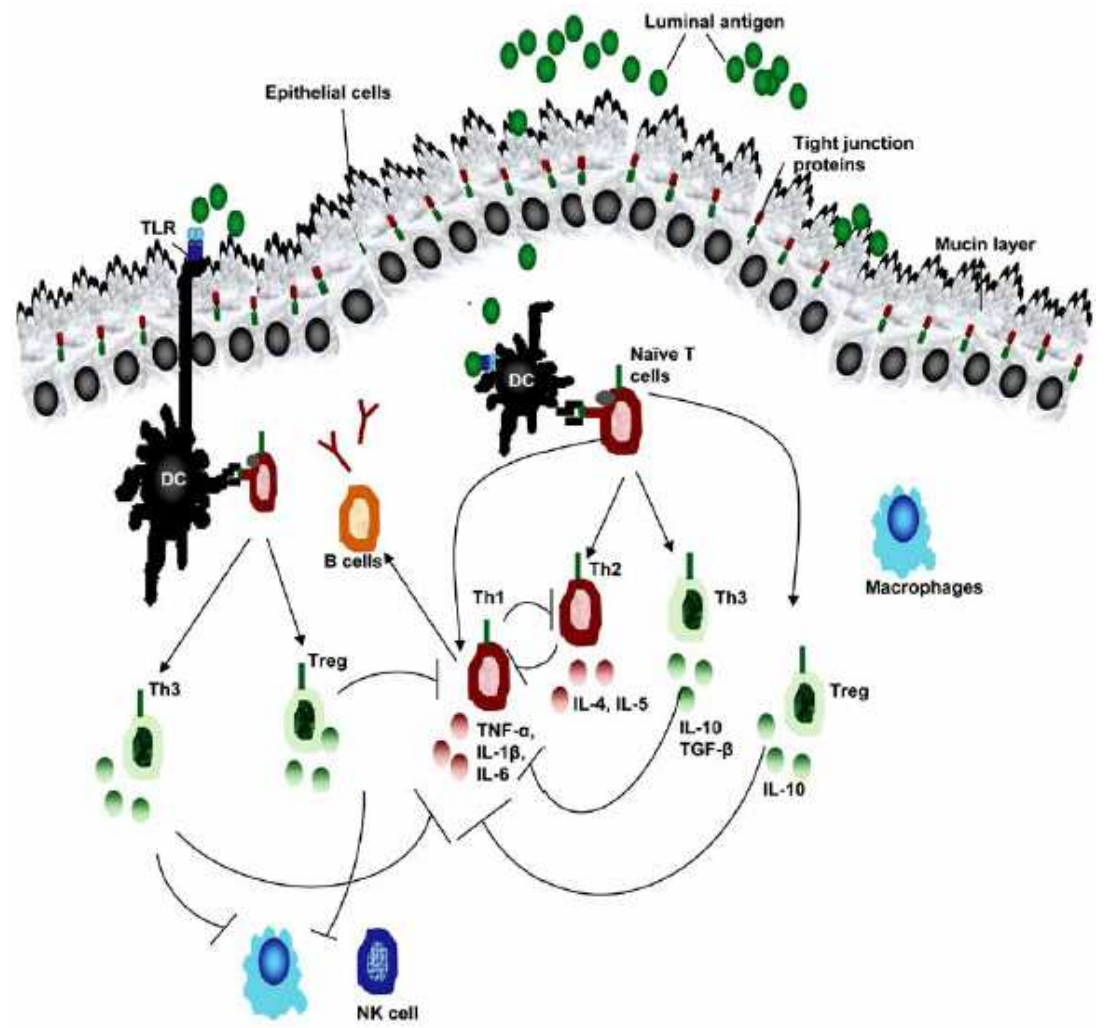

Fig. 1. Intestinal mucosal (immune) homeostasis in healthy state (Dharmani $P, 2008)$

Mucosal homeostasis is maintained by professional APCs (DC) that differentiate pathogens from commensals through TLRs and leads to balanced differentiation of naive T cells into effector T cells (Th1, Th2 and Th17) against pathogens and Treg and Th3 cells to control the inflammation in absence of pathogens. Epithelial cells lining, tight junction proteins and mucus layer remains intact separating luminal antigen from immune cells.

\subsection{PPRs}

The recognition, processing and presentation of the luminal antigen is carried out by both dedicated APCs such as dendritic cells (DCs) and macrophages, and non-professional APCs such as epithelial cells. Two PRRs namely Toll-like receptor (TLR) and Nucleotide binding Oligomerization Domans (NOD) proteins are involved in luminal antigen recognition. TLRs are membrane bound receptors while NOD proteins are expressed in the cytosols of APCs. PPRs recognize molecules shared by pathogens but distinguishable from commensal 
microbes. Such unique microbial components are collectively referred to as pathogenassociated molecular patterns (PAMP), which include CpG regions of methylated DNA, viral specific ssRNA and dsRNA, peptidoglycans, muramyl dipeptide (MDP) and lipopolysaccharides. Both animal and in vitro studies have shown and exaggerated TLR expression (especially TLR4), that leads to an incorrect immune response (Th1 or Th17 mediated) against resident microflora. NOD2/CARD15 gene is famous as it is the first predisposing gene of $\mathrm{CD}$. Mutations of the NOD2/CARD15 gene have conclusively associated with $\mathrm{CD}$. Both gain and loss of expression of NOD2 gene contributes in disturbing mucosal homeostasis. Loss of NOD2 expression cause change in TLR signaling pathway and thus leads to an increase in Th1 cytokine and defensins. In contrast, gain of expression eventually leads to more Th1 response against the MDP component of microbes.

\section{$1.3 \mathrm{~T}$ cell polarisation}

$\mathrm{T}$ helper cells have been classified as either Th1 or Th2 on the basis of function and according to their ability to elaborate specific cytokines. Th1 cells orchestrate cell-mediated immune responses and are characterized by their ability to secrete IL-2, IFNY and TNF $\beta$. IFNY activates APCs and macrophages to produce IL-12, thereby driving Th1 cells to produce even larger amounts of Th1 cytokines. In contrast, Th2 cells mediate humoral responses and secrete IL-4, IL-5, IL-6, IL-10 and IL-13. These subsets regulate each other reciprocally through key cytokines. IFN $\gamma$, produced by Th1 cells, suppresses the development of Th2, whereas IL-4, IL-10 and IL-13, secreted by Th2 cells, inhibit Th1 responses (Fig 2).CD is thought to be associated with Th1 cell cytokines and inhibition of Th1 responses could represent a significant goal in the treatment of CD. Intestinal Th1 activation and cytokine release are associated with the generation of activated matrix metalloproteinases (MMPs), which are essential mediators of tissue destruction.

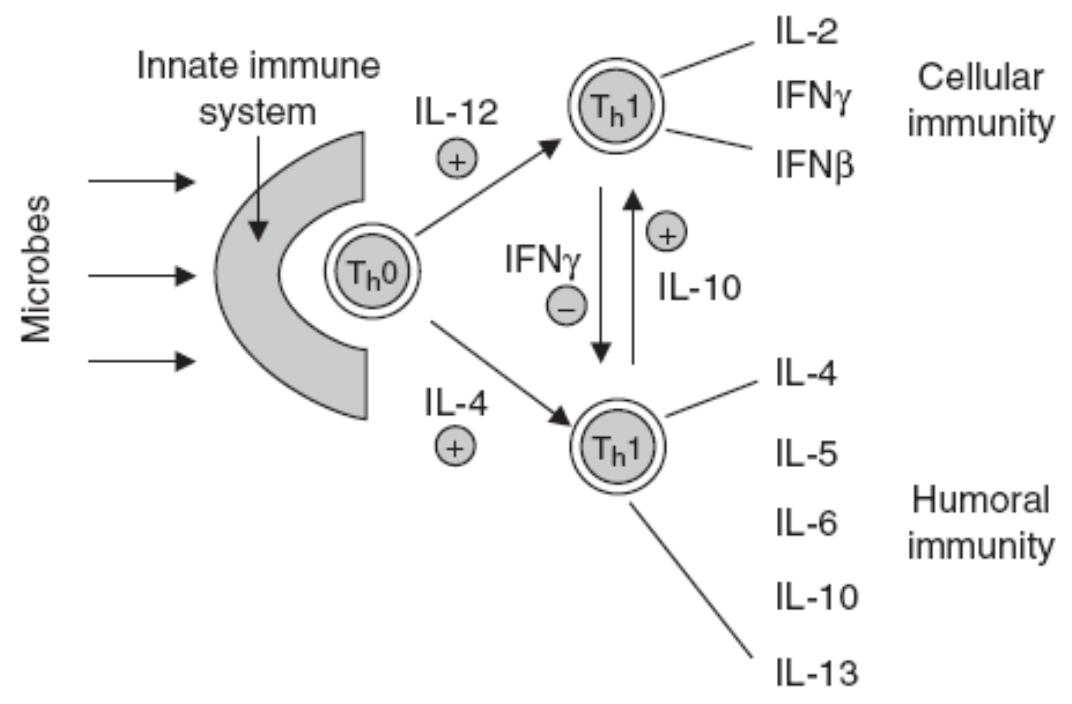

Fig. 2. T-helper (Th)-1 and Th2-mediated cytokine profiles and immune response. IL = interleukin; IFN = interferon ( Ardizzone S, 2005). 


\section{Common categories of biological therapy}

Traditionally, the therapeutic goals in $C D$ include $i$ induction of a rapid response, ii maintenance of glucocorticoid-free remission, iii minimization of complications and surgery, iv prevention of disease-related mortality, $\mathrm{v}$ improvement in patients' quality of life, vi minimization of the adverse effects of treatment, and vii the so-called 'deep remission' (i.e. simultaneous clinical, biological and endoscopic remission). Both mucosal healing and deep remission need to be evaluated for their prediction of long-term outcome and benefit/risk ratio if treatment escalation becomes necessary.

Existing CD therapies are an amalgamation of pharmacological agents including 5aminosalicylate compounds, corticosteroids, and immunosuppressors (azathioprines, 6mercaptopurine, methotrexate, tacrolimus and cyclosporine). Novel biological therapies have been developed in recent years based on better understanding of specific immunopathological processes in intestinal inflammation. There are several categories of biologic therapies that are relevant to CD: 1) antibody-based therapy (monoclonal antibodies, receptor fusion proteins, and soluble receptor antagonists), 2) recombinant cytokines, 3) nucleic acid-based therapies, 4) hormones and growth factors, 5) cell and gene therapy. At present, the biotechnology therapies that are being used in clinical practice or investigated for the treatment of $\mathrm{CD}$ are predominantly proteins, usually delivered intravenously or subcutaneously. The types of therapeutic proteins in used include recombinant human proteins with immunoregulatory effects, monoclonal antibodies (chimeric, humanized and fully human) and fusions proteins. Here we chose to focus on therapies that have been used in clinical trials in CD, some of which have been already or may be in the near future approved for commercial daily use (table 1).

\begin{tabular}{|c|c|c|c|c|}
\hline Therapy & Target & Origin & Efficacy & Side effects \\
\hline \multicolumn{5}{|c|}{ Inhibition of pro-inflammatory cytokines } \\
\hline Infliximab & \multirow{6}{*}{ TNFa } & $\begin{array}{l}\text { Mouse/human } \\
\text { chimeric mab }\end{array}$ & $\begin{array}{l}\text { Safe, being used in } \\
\text { treatment }\end{array}$ & $\begin{array}{l}\text { Risk of malignancy and infection, } \\
\text { infusion site reactions }\end{array}$ \\
\hline Adalimumab & & $\begin{array}{l}\text { Human IgG1 } \\
\text { mab }\end{array}$ & $\begin{array}{l}\text { Safe, being used in } \\
\text { treatment }\end{array}$ & $\begin{array}{l}\text { Risk of malignancy and infection, } \\
\text { infusion site reactions }\end{array}$ \\
\hline CDP571 & & Fusion protein & Still in clinical trial & $\begin{array}{l}\text { Risk of malignancy and infection, } \\
\text { infusion site reactions }\end{array}$ \\
\hline Onercept & & $\begin{array}{l}\text { Human soluble } \\
\text { TNFa p55 } \\
\text { receptor }\end{array}$ & Still in clinical trial & Local reaction \\
\hline Etanercept & & Fusion protein & \begin{tabular}{|l|} 
Safe but \\
ineffective in \\
treatment CD
\end{tabular} & $\begin{array}{l}\text { Itching, pain, swelling and redness } \\
\text { at the site of injection }\end{array}$ \\
\hline CDP-870 & & $\begin{array}{l}\text { PEGylated anti- } \\
\text { TNFa ab }\end{array}$ & Under clinical trial & No reported major side effects \\
\hline IL-1 R ab & IL-1 R & $\begin{array}{l}\text { Recombinant IL- } \\
1 \text { R antagonist }\end{array}$ & $\begin{array}{l}\text { No double } \\
\text { placebo control } \\
\text { tried yet }\end{array}$ & Not fully established \\
\hline $\begin{array}{l}\text { Anti-IL-6 R } \\
\mathrm{ab}\end{array}$ & IL-6 R & Human mab & Under clinical trial & Not fully established \\
\hline $\begin{array}{l}\text { Anti-IL-12 } \\
\text { p40 ab }\end{array}$ & IL-12 & Human mab & Safe and effective & Possible reactivation of asthma \\
\hline Fontolizumab & $\mathrm{IFN \gamma}$ & Human mab & $\begin{array}{l}\text { Under phase } \\
\text { IIclinical trial }\end{array}$ & Not fully established \\
\hline
\end{tabular}




\begin{tabular}{|c|c|c|c|c|}
\hline \multicolumn{5}{|c|}{ Supplementation of regulatory cytokines } \\
\hline Tenovil & IL-10 & $\begin{array}{l}\text { Recombinant } \\
\text { cytokine }\end{array}$ & $\begin{array}{l}\text { Failed to show } \\
\text { efficacy in phase II } \\
\text { clinical trial }\end{array}$ & Reaction at injection site \\
\hline $\begin{array}{l}\text { Turbo } \\
\text { probiotics }\end{array}$ & IL-10 & $\begin{array}{l}\text { Lactobacillus } \\
\text { lactis }\end{array}$ & $\begin{array}{l}\text { Effective in clinical } \\
\text { study }\end{array}$ & Not fully established \\
\hline IL-11 & IL-11 & $\begin{array}{l}\text { Recombinant } \\
\text { cytokine }\end{array}$ & $\begin{array}{l}\text { No efficacy in } \\
\text { phase II clinical } \\
\text { trials }\end{array}$ & Not fully established \\
\hline \multicolumn{5}{|c|}{ Inhibition of proliferation of T cells } \\
\hline Visilizumab & CD3 & Human ab & Under clinical trial & Not fully established \\
\hline Daclizumab & $\begin{array}{l}\text { achain of IL- } \\
2 \mathrm{R}\end{array}$ & Human mab & $\begin{array}{l}\text { Failed to show } \\
\text { efficacy in phase II } \\
\text { clinical trial }\end{array}$ & Hypersensitivity \\
\hline Basiliximab & $\begin{array}{l}\text { a chain of } \\
\text { IL-2R }\end{array}$ & Human mab & Under clinical trail & $\begin{array}{l}\text { Mild dizziness, nausea, rashes on } \\
\text { skin }\end{array}$ \\
\hline \multicolumn{5}{|c|}{ Blocking molecule involved in leukocyte adhesion } \\
\hline Natalizumab & Integrin-a4 & Human mab & Approved by FDA & $\begin{array}{l}\text { Sometimes causes fatal brain } \\
\text { infection (progressive multifocal } \\
\text { leukoencephalopathy) }\end{array}$ \\
\hline MLN-02 & a4 $\beta 7$ integrin & Human mab & Under clinical trial & Infusion reaction \\
\hline \multicolumn{5}{|c|}{ Supplementation of growth factor } \\
\hline somatropin & & $\begin{array}{l}\text { Recombinant } \\
\text { human growth } \\
\text { hormone }\end{array}$ & Under clinical trial & Not intense severe adverse reactions \\
\hline \multicolumn{5}{|c|}{ Nucleic acid based therapies } \\
\hline alicaforsen & ICAM-1 & \begin{tabular}{|l|} 
Antisense \\
phosphorothioat \\
e oligonucleotide
\end{tabular} & $\begin{array}{l}\text { Under phase III } \\
\text { clinical trials }\end{array}$ & Not fully established \\
\hline \multicolumn{5}{|c|}{ Recompositon of intestinal microflora } \\
\hline Probiotics & $\begin{array}{l}\text { Reconstituti } \\
\text { on of } \\
\text { commensal } \\
\text { microbes } \\
\end{array}$ & $\begin{array}{l}\text { Combination of } \\
\text { different bacteria }\end{array}$ & $\begin{array}{l}\text { Under clinical } \\
\text { trials }\end{array}$ & \\
\hline helminthes & $\begin{array}{l}\text { Inhibition of } \\
\text { excessive } \\
\text { immune } \\
\text { response }\end{array}$ & Helminthes & $\begin{array}{l}\text { Under clinical } \\
\text { trials }\end{array}$ & Not fully established \\
\hline \multicolumn{5}{|c|}{ Reconstitution of the immune system } \\
\hline $\begin{array}{l}\text { Hematopoietic } \\
\text { stem cell } \\
\text { transplantation }\end{array}$ & $\begin{array}{l}\text { Replacement } \\
\text { of defected } \\
\text { hematolymp } \\
\text { hatic cells }\end{array}$ & $\begin{array}{l}\text { Infusion of the } \\
\text { healthy } \\
\text { hematopoietic } \\
\text { cells }\end{array}$ & Under clinical trial & $\begin{array}{l}\text { Toxic effects of high dose } \\
\text { chemotherapy and post HCT } \\
\text { infections }\end{array}$ \\
\hline
\end{tabular}

R: receptor; ab: antibody; mab: monoclonal antibody; ICAM-1: intracellular adhesion molecule-1

Table 1. Biological Therapies targeting different factors (Dharmani P, 2008)

\section{Evaluations of biological treatment}

\subsection{Anti-TNF $\alpha$ therapies}

Anti-TNFa $\mathrm{mAb}$ is the first agent that was approved for patients with persisting signs and symptoms of disease refractory impact in achieving new therapeutic goals. Till now, several 
anti-TNFa reagents have been developed and used to inhibit TNFa in patients with CD, including the mouse/human chimeric monoclonal antibody (infliximab), the humanized monoclonal antibody CDP571 and D2E7 (adalimumab), the human soluble TNFa p55 receptor (onercept), the p75 soluble TNFa receptor fusion protein (etanercept), and the polyethylene glycol (PEG)ylated anti-TNFa antibody fragment CDP-870 (certolizumab pegol). Peyrin B L and his colleagues performed a meta-analysis including 21 trials to evaluate safety and efficacy of tumor necrosis factor (TNF) antagonists for Crohn's disease (Peyrin-Biroulet L, 2008). They concluded that infliximab, adalimumab, and certolizumab are effective in luminal Crohn's disease. Efficacy of anti-TNF agents other than infliximab in treating fistulizing Crohn's disease requires additional investigations. Longer duration of following-up and larger number of patients are required to better assess the safety profile of TNF antagonists in CD. We also conducted a meta-analysis about anti-TNFa reagents treating CD. As a result, Fifteen RCTs articles with high quality were selected. Compared with placebo, anti-TNF-a agents achieved significantly higher rates of clinical response ( $44.9 \%$ vs. $30.0 \%, \mathrm{RR}=1.39,95 \%$ CI: $1.16 \sim 1.67, P=0.0004)$ and clinical remission $(29.3 \%$ vs. 18.7\%, RR=1.63, 95\% CI: 1.26 2.09, P=0.0001). We concluded that Anti-TNF-a agents are superior to placebo in the treatment of $\mathrm{CD}$ and have similar risks of adverse events and serious adverse events. Long-term trials with large samples are needed for the assessment of its safety and tolerance. Table 2 lists the administrations of some of these agents.

\subsubsection{Infliximab}

Infliximab is the only biologic agent approved in the China, US and Europe for the treatment of patients with moderate to severe CD unresponsive to conventional therapy or a full and adequate course of corticosteroids and immunosuppressive therapy, and for patients with actively draining fistulas.

The first randomized placebo-controlled trial of infliximab focused on response rates 4 weeks after a single-blind infusion (Targan SR, 1997). All patients presented moderate to severely active disease despite other treatments or had previously been unresponsive to treatment with immunomodulators. A single infusion yielded a decrease in the CDAI of $\geq 70$ points 4 weeks after infusion in $65 \%$ of the patients treated with infliximab, compared with a $17 \%$ response in the placebo group. The highest response rate was observed in patients receiving infliximab $5 \mathrm{mg} / \mathrm{kg}(81 \%)$, with lower response rates in those treated with 10 or 20 $\mathrm{mg} / \mathrm{kg}$ ( $50 \%$ and $64 \%$, respectively).

Rutgeerts et al conducted a study to find out whether repeated infusions of infliximab could maintain the response (Rutgeerts $\mathrm{P}$, 1999). Seventy-three patients were randomized to receive infliximab or placebo $10 \mathrm{mg} / \mathrm{kg}$ every 8 weeks for 36 weeks and were followed up until week 48. At week 44,52.9\% patients received infliximab achieved maintenance of remission, compared with $20 \%$ of placebo-treated patients. Quality of life was consistently better (using a inflammatory bowel disease questionnaire) and serum concentrations were maintained at remission levels.

The results were confirmed in the recent multicenter, randomized, placebo-controled, double-blind phase III clinical trial: the ACCENT I (A Crohn's disease Clinical trial Evaluating infliximab in a New long-term Treatment regimen) study (Hanaeur SB, 2002). Five hundred and seventy three patients with active $C D$ received infliximab $5 \mathrm{mg} / \mathrm{kg}$ at week 0 and were assessed of response at week 2 . The responders were then randomized into 
3 groups. Group I received placebo at week 2 and 6 and then every 8 weeks until week 46 . Group II received $5 \mathrm{mg} / \mathrm{kg}$ infliximab at the same time points. Group III received $5 \mathrm{mg} / \mathrm{kg}$ infliximab at week 2 and 6 , but followed by $10 \mathrm{mg} / \mathrm{kg}$ every 8 weeks until week 46 . The endpoints were the proportion of patients who responded at week 2 and were in remission $(\mathrm{CDAI}<150)$ at week 30 , and the time to loss of response up to week 54 in patients who responded. At week 2, 335 patients (58\%) responded to infliximab. At week 30, 23 of 110 (21\%) patients in group I were in remission, compared with 44 of $113(39 \%)$ in group II $(\mathrm{P}=0.003)$ and 50 of $112(45 \%)$ in group III $(\mathrm{P}=0.0002)$. The study suggested that patients that were repeatedly administrated with infliximab every 8 weeks are more likely acquiring sustained clinical remission than those with single infusion. The safety was consistent with those in other clinical trials and serious infections were similar across the three groups.

\begin{tabular}{cccc}
\hline & Infliximab & Adalimumab & Certolizumab pegol \\
\hline Dosage & $5 \mathrm{mg} \mathrm{kg}^{-1}$ & $40 \mathrm{mg}$ & $400 \mathrm{mg}$ \\
Route of & i.v. & s.c. & s.c. \\
administration & 8 weeks & 2 weeks (e.o.w) & 4 weeks \\
Dosing intervals & $5 \mathrm{mg} \mathrm{kg}^{-1}$ weeks 0, & $\begin{array}{c}168 / 80 \mathrm{mg}(\mathrm{FDA}) \\
\text { or } 80 / 40 \mathrm{mg}\end{array}$ & $400 \mathrm{mg}$ weeks $0,2,4$ \\
Induction & 2,6 & (EMA) & \\
& $10 \mathrm{mg} \mathrm{kg}^{-1}$ or every & $40 \mathrm{mg} \mathrm{e.w.}$ & 400 mg e. o. w. \\
Dose escalation & $4-6$ weeks & &
\end{tabular}

i.v., intra venous; s.c., subcutaneous; e.w., every week; e.o.w., every other week; EMA, European Medicines Agency; FDA, Food and Drug Administration

Table 2. Administrationof biologicalagents in inflammatory bowel disease (Nielsen, 2011)

A study was conducted early in 1999 by Present DH, et al to investigate whether infliximab had the efficacy in healing enterocutaneous fistulas. In their study, 94 adult CD patients with fistulas were randomly assigned to receive placebo, $5 \mathrm{mg} / \mathrm{kg}$ inflximab or $10 \mathrm{mg} / \mathrm{kg}$ inflximab at weeks 0,2 and 6 . As a result, $55 \%$ patients assigned to receive $5 \mathrm{mg} / \mathrm{kg}$ infliximab and $38 \%$ patients assigned to receive $10 \mathrm{mg} / \mathrm{kg}$ infliximab had closure of all fistulas, as compared with $13 \%$ of the patients assigned to placebo. Adverse events were similar for the $5 \mathrm{mg} / \mathrm{kg}$ infliximab group and the placebo group, but there was a trend toward more adverse events in the $10 \mathrm{mg} / \mathrm{kg}$ group.

The multicenter, randomized, placebo-controlled ACCENT II trial further confirmed the efficacy of infliximab as maintenance therapy for fistulas in CD (Sands BE, 2002). After 14week lead-in period, 195 of $282(69 \%)$ patients responded. The responders were then randomized to receive either $5 \mathrm{mg} / \mathrm{kg}$ infliximab or placebo every 8 weeks. Forty-eight percent of the infliximab group maintained fistula response at week 30 compared with $27 \%$ of the placebo group. At week $54,36 \%$ of the infliximab group had a complete absence of draining fistulas compared with $19 \%$ of the placebo group.

Infliximab is also efficacy for patients who are intolerant of, resistant to or dependent on steroids. On study showed that of the first 100 patients administered infliximab, 29 of 40 (73\%) were able to completely withdraw from steroids (Ricart E, 2001). At study entry in the ACCENT I, more than half of the patients were taking corticosteroids; one third of the patients receiving maintenance infliximab discontinued steroids and maintained clinical benefit. 
There is also evidences that infliximab likely has a role in treating some extraintestinal manifestations, such as ankylosing spondylitism peripheral arthritis, pyoderma gangrenosum and erythema nodosum. $\mathrm{CD}$ patients are at increased risk of low bone mineral density (BMD), with reports of prevalence of osteopenia and osteoporosis as high as $50 \%$ and $10 \%$, respectively. Infliximab may improve BMD in CD patients. A prospective study was conducted by Abreu et al to evaluate the effect of infliximab on surrogate markers of bone turnover in $38 \mathrm{CD}$ patients. The data obtained demonstrated that bone synthesis markers were increased in the infliximab-treated patients (Abreu MT, 2006). Longer-term studies are needed to clarify the effect of infliximab on BMD.

Although efficacy of infliximab for the treatment of $\mathrm{CD}$ has clearly been demonstrated, serious side effects have been reported. In particular, these include acute infusion reactions, delayed hypersensitivity reactions, infections including reactivation of tuberculosis (TB), autoantibody formation, and a Lupus-like syndrome. Acute infusion reactions are adverse events that occur during infusion or within 2 hours after completion of the infusion. According to the manufacturer's drug insert, 22\% of patients administered infliximab occurred compared with $9 \%$ of patients administered placebo (Lichtenstein GR, 2011). Delayed-hypersensitivity reactions can occur several days after infusion. Symptoms include severe pruritus, headaches, hand, facial or lip swelling, myalgias, rash, sore throat, and dysphagia. In the ACCENT I study, the frequency of delayed hypersensitivity reaction was $2 \%$. Infections have been observed with pathogens, including viral, bacterial, fungal, and protozoal organisms. The majority of infections involved the respiratory and urinary tracts. Reactivation of latent TB after infusion with infliximab has occurred, mandating screening of patients for TB prior to infusion. A purified protein derivative (PPD) should be administered to all patients being considered for treatment with infliximab, with the results interpreted according to the risk atrata adapted from the American Thoracic Society (ATS), patients with a positive PPD should undergo a chest radiograph. Lymphoma has been reported in association with all 3 approved TNFa antagonists. A meta-analysis performed by Siegel et al suggested that the risk of lymphoma was increased in patients receiving infliximab for CD.

Since infliximab contains exogenous proteins, it can prompt the formation of antibodies-toinfliximab (ATIs) and thus may lead to the infusion reaction or loss of response. In ACCENT I trial, 64/442 (14.5\%) developed antibodies. Patients administered a single dose of infliximab had higher incidence of ATI formation than those administered scheduled maintenance regiments of 5 or $10 \mathrm{mg} / \mathrm{kg}$ ( $28 \%$ vs $9 \%$ and $6 \%$, respectively). The clinical response rates were similar in the patients regardless of their ATI status. The infusion reactions were more common in the ATI-positive patients compared with the ATI-negative group $(16 \%$ vs $8 \%)$. The majority of the infusion reactions were mild to moderate.

\subsubsection{Adalimumab}

Adalimumab (first named D2E7) is a subcutaneously administered, recombinant, fully human, IgG1 monoclonal antibody that binds with high affinity and specificity to human TNFa, thus modulating its biologic functions by blocking the interaction with p55 and p75 cell surface TNF receptors. It is available in a number of countries, including the US and EU countries.

In CD, adalimumab has received both FDA and EMEA approval with the following indications: 1) for reducing the signs and symptoms and inducing and maintaining clinical 
remission in adults with moderately to severely active $C D$ who have had an inadequate response to conventional therapy, and 2) for reducing the signs and symptoms and inducing clinical remission in these patients if they have also lost response or are intolerant to IFX.

Therefore, adalimumab is the second biologic therapy approved for the treatment of patients with moderately to severely active CD. Adalimumab is administered by subcutaneous injection, as commercially available prefilled pen (HUMIRA Pen) containing $0.8 \mathrm{~mL}(40 \mathrm{mg})$ of drug.

The recommended adalimumab induction dose regimen for adult patients with moderatesevere CD is usually $80 \mathrm{mg}$ at week 0 followed by $40 \mathrm{mg}$ at week 2 . In case there is a need for a more rapid response to therapy, the regimen with $160 \mathrm{mg}$ at week 0 (dose can be administered as 4 injections in one day or as 2 injections per day for 2 consecutive days) and $80 \mathrm{mg}$ at week 2 can be used with the awareness that the risk for adverse events is higher during induction. After induction treatment, the recommended dose is $40 \mathrm{mg}$ every other week via subcutaneous injection as maintenance treatment. For induction treatment, adalimumab should be given in combination with corticosteroids. Adalimumab can be given as monotherapy in case of intolerance to corticosteroids or when continued treatment with corticosteroids is inappropriate (Cassinotti A, 2008).

In a phase III, placebo-controlled, dose-ranging induction trial named CLASSIC I (CLinical Assessment of adalimumab Safety and efficacy Studied as Induction therapy in Crohn's disease), 299 patients with moderate to severe CD, naive to anti-TNF therapy were randomized to 4 groups. Patients in group I received adalimumab $40 \mathrm{mg}$ at week 0 and $20 \mathrm{mg}$ at week 2; patients in group II received adalimumab $80 \mathrm{mg}$ at week 0 and $40 \mathrm{mg}$ at week 2; patients in group III received adalimumab $160 \mathrm{mg}$ at week 0 and $80 \mathrm{mg}$ at week 2; patients in group IV received placebo at the same points. All the patients were followed through week 4. A response was defined as a CDAI score reduction of $\geq 70$ points (70-point response) or of $\geq 100$ points (100-point response) from week 0 , while remission was defined as a CDAI score $<150$. At week 4 , patients in group II and group III showed a significantly greater remission rate $(24 \%$ and $36 \%)$ than patients in group IV (12\%) ( $\mathrm{P}=0.004$ among the 3 groups). There was a linear dose response across the 3 adalimumab treatment groups at week 4 for the endpoints of remission and 100-point response, with only the highest dose group demonstrating statistical significance in the pairwise comparisons with placebo: $36 \%$ vs $12 \%$ for remission $(p=0.001)$ and $50 \%$ vs $25 \%(p=0.002)$ for the 100-point response; the 70-point response was also significantly higher in the adalimumab recipients than placebo, both for the $160 / 80 \mathrm{mg}$ dosage $(59 \%$ vs $37 \% ; \mathrm{p}=0.007)$ and for the $80 / 40 \mathrm{mg}$ group $(59 \%$ vs $37 \%$; $\mathrm{p}=$ 0.01 ). The reduction of CDAI from baseline was evident as early as week 1 . Only $11 \%$ $(32 / 299)$ of the randomized patients had draining enterocutaneous or perianal fistulas at baseline and were unevenly distributed across the treatment groups. The rates of fistula improvement and remission for the ADA-treated patients and those receiving placebo were not significantly different, but the number of these patients precluded a powered analysis (Hanauer SB, 2006).

A total of 276 patients who completed the 4-week CLASSIC-I trial entered a long-term extension study named CLASSIC-II (Sandborn WJ, 2007). This was a randomized, placebocontrolled, maintenance follow-up trial, demonstrating that adalimumab $40 \mathrm{mg}$ every other week or weekly was superior to placebo in maintaining remission for 1 year in patients with moderate to severe CD naive to anti-TNF agents who achieved remission with adalimumab induction therapy. 
Eligible patients (belonging to the pool of CLASSIC-I enrolled patients) were treated with adalimumab $40 \mathrm{mg}$ at week 0 (corresponding to week 4 of CLASSIC-I) and week 2 . Those in remission at both week 0 and week $4(n=55)$ were randomized to receive adalimumab 40 mg every other week $(n=19)$, adalimumab $40 \mathrm{mg}$ weekly $(\mathrm{n}=18)$, or placebo $(\mathrm{n}=18)$, through 56 weeks.

At week 56, remission was maintained in $79 \%, 83 \%$, and $44 \%$ of patients in the respective groups (primary endpoint), with a statistically significant difference between each adalimumab group and placebo $(\mathrm{p}<0.05)$. The 100-point response at week 56 was also better in adalimumab recipients ( $79 \%$ vs $89 \%$ vs $56 \%$, respectively), as was the 70 -point response rates $(79 \%$ vs $89 \%$ vs $72 \%)$, although differences between groups were not statistically significant.

\subsubsection{CDP571}

CDP571 was a humanised monoclonal antibody to human TNF-a. It was constructed by linking the complementarity determining regions (CDR) of a murine antihuman TNF monoclonal antibody to a human IgG4 antibody. A total number of 396 patients with moderate to severe $\mathrm{CD}$ were included in a randomized, double blind and placebo controlled trial in 2004. The patients were received intravenous $10 \mathrm{mg} / \mathrm{kg}$ CDP571 or placebo every 8 weeks to week 24 and were followed up to week 28 . Clinical response was defined as a decrease in the CDAI to $\geq 100$ points or remission (CDAI score $\leq 150$ points) at week 28 . Initial clinical response occurred in 90/263 (34.2\%) CDP571 patients and 28/32 (21.2\%) placebo patients $(\mathrm{P}=0.011)$. At week 28, 80/263 (30.4\%) CDP571 patients and 31/132 $(23.5 \%)$ placebo patients achieved clinical response $(\mathrm{P}=0.102)$. Adverse events were similar in both groups. A post hoc analysis of a subgroup of patients with CRP concentrations $\geq 10 \mathrm{mg} / \mathrm{L}$ demonstrated significantly increased response rates for CDP571 10mg/ $\mathrm{kg}$ at both week 2 and 28 (Sandborn WJ, 2004). Two controlled trials failed to demonstrate a steroid-sparing benefit of CDP571 in patients with steroid-dependent CD. Further clinical development of CDP571 for the treatment of CD has been discontinued.

\subsubsection{Certolizumab pegol}

Certolizumab pegol (CDP870) is a humanized TNFa Fab monoclonal antibody fragment linked to polyethylene glycol that is administered subcutaneously. A phase III, randomized, double-blind, multicenter study that assessed the efficacy and tolerability of certolizumab in patients with moderate to severe $\mathrm{CD}$ showed a modest improvement in response rates, as compared with placebo but no significant improvement in remission rates (Sandborn WJ, 2007). In addition, patients who had a response to induction therapy with certolizumab were more likely to have maintained response and remission at 26 weeks with continued treatment compared with a switch to placebo.

\subsection{Other novel biological therapies}

\subsubsection{Natalizumab}

Natalizumab is a recombinant humanized monoclonal antibody IgG4, with a molecular weight of $149 \mathrm{kDa}$. It contains $95 \%$ human peptide sequences and only $5 \%$ mouse sequences in the complementary determining regions. It inhibits both a $4 \beta 7$-integrin/MAdCAM-1 interaction and a $4 \beta 1 /$ VCAM-1 binding.

ENACT-1 (Efficacy of Natalizumab as Active Crohn's Therapy) is a randomized doubleblind, placebo-controlled Phase III trial (Sandborn WJ, 2005), in which 905 patients were 
randomly assigned in a 4:1 ratio to receive an intravenous infusion of $300 \mathrm{mg}$ natalizumab or placebo at week 0,4 and 8 . The patients were then followed until week 12 . The primary end point was the proportion of patients who had a clinical response ( $\triangle \mathrm{CDAI}$ score $\geq 70$ points). No difference in the response remission (CDAI < 150) rates was seen between the natalizumab group and the placebo group ( $\mathrm{P}=0.051$ and $\mathrm{P}=0.12$, respectively). A significant difference of CRP was present in the subgroup of 660 patients who had a baseline CRP level more than $2.87 \mathrm{mg} / 1$ compared with the placebo group.

The patients who responded in the ENACT-1 trial were randomly reassigned in a 1:1 ration to receive either natalizumab $300 \mathrm{mg}$ intravenously every 4 weeks or placebo and were followed up to 36 weeks (ENACT-2) (Sandborn WJ, 2004). At week 36, 61\% of natalizumab patients had a sustained response compared with $28 \%$ in the placebo group $(\mathrm{P}<0.001)$. The remission rates was also significantly higher in the natalizumab group (44\%) than in the placebo group $(26 \%)$ at week $36(\mathrm{P}=0.003)$. Forty five percent of patients in the natalizumab group were no longer taking corticosteroids and remained in remission at week 36 compared with $22 \%$ of patients in the placebo group $(\mathrm{P}=0.003)$.

Natalizumab should not be given with immunomodulators (e.g.6-mercaptopurine, azathioprine, cyclosporine or methotrexate) or inhibitors of TNF-a. Corticosteroids should be tapered.

Natalizumab is not approved in Europe for the treatment of CD. It is available in the USA under a special restricted distribution program called CD-TOUCH $\left(\mathrm{Tysabri}^{\circledR}\right.$ outreach unified commitment for health). Under this program, prescribers, pharmacies, infusion centers and patients are made aware of risks of opportunistic infections, including PML. Patients are evaluated 3 months after the first infusion, 6 months after the first infusion and every 6 months thereafter. Any serious opportunistic or atypical infections are reported (Bickston SJ, 2010).

\subsubsection{Fontolizumab}

Fontolizumab is a humanized IgG1 antibody with high binding affinity and specificity for IFNY By inhibiting the binding of IFNY to its cellular receptor, fontolizumab prevents downstream physiologic effects, such as expression of major histocompatibility complex class II molecules.

In a Phase II, randomized, double-blind, placebo-controlled study, 201 patients with CDAI scores between 250 and 450 were randomized to receive an initial intravenous dose of 1.0 or $4.0 \mathrm{mg} / \mathrm{kg}$ fotolizumab or placebo, and then were received $0.1 \mathrm{or} 1.0 \mathrm{mg} / \mathrm{kg}$ fontolizumab or placebo every 4 weeks. The primary endpoint of efficacy evaluations was the proportion of patients who achieved a clinical response (defined as a decrease in the CDAI of $\geq 100$ points from baseline levels without an accompanying increase in dose of concomitant medications for $C D$ ) by day 29. Secondary endpoints were clinical response rates on days 43 , 57, 85, 113, and at the 3-month follow-up visit. The response rates were similar in all treatment groups $(31 \%-38 \%)$ at day 29 . At subsequent timepoints a significantly greater proportion of patients in the $1.0 \mathrm{mg} / \mathrm{kg}$ intravenous / $1.0 \mathrm{mg} / \mathrm{kg}$ subcutaneous fontolizumab group had clinical response and significantly greater improvement in the CDAI score compared with patients who received placebo. The CRP levels were significantly improved in the fontolizumab groups. The overall frequency of adverse events was similar in all groups (58\%-75\%) (Reinisch W, 2010). Further clinical studies with fontolizumab for the induction and maintenance of remission in patients with $\mathrm{CD}$ are anticipated. 


\subsubsection{Anti-IL-12 P40 antibody}

IL-12 is a heterodimeric molecule composed of IL-12 p40 and IL-12 p35 subunits. The p40 subunit is also a component of IL-23, in which p40 forms a heterodimer with a p19 subunit. IL12/23 is a key cytokine in the Th1/Th17 development and is abundantly produced in the gut of CD patients. IL-12 p40 is, therefore, a pivotal target for the treatment of CD.

A double-blind, placebo controlled randomized study of a humanized IgG1 monoclonal antibody against IL-12 p40 (ABT-874) was performed in 79 patients with active CD (Mannon PJ, 2004). The patients were randomized to receive seven weekly injections of $1 \mathrm{or} 3 \mathrm{mg} / \mathrm{kg}$ anti-IL-12 or placebo subcutaneously either with or without 4 wk intervals between the first two injections. The patients who received $3 \mathrm{mg} / \mathrm{kg}$ anti-IL-12 for $7 \mathrm{wk}$ showed a significantly greater clinical response rate than the patients treated with a placebo $(75 \%$ vs $25 \%)$. The production Th1 proinflammatory cytokines from patient's colonic lamina propria mononuclear cells dramatically decreased after the anti IL-12 therapy. The most frequent adverse event was a local reaction at the injection site, which was observed with a greater rate in the anti IL-12 treated group than in the placebo-treated group. No serious side effects were observed during the anti-12 therapy. Anti IL-12 therapy is therefore considered to be a safe and effective treatment for active CD.

\section{Conclusion}

There are multiple biological therapies based on different targets in addition to those we introduced above. More clinical studies for the efficacy and safety should be conducted. Overall, the biological treatments differ from conventional CD therapy in several aspects: They are usually peptides or proteins; are administered parenterally; target specific molecules, cells, or processes; and their manufacture is more sophisticated and more expensive than the conventional drugs. The development of biological therapies is based on better understanding of mucosal intestinal processes in homeostasis and uncontrolled inflammation and is possible due to great biotechnological progress such as genetic engineering and development of novel vehicles.

\section{Acknowledgment}

We acknowledge Dr. Jingjing Lian for the efforts of the literature retrieval and the works of meta-analysis of efficacy of anti-TNF reagents in patients with active CD.

\section{References}

Abreu MT, Kam LY, Vasiliauskas EA, Kam Ly, Vora P, Martyak LA, Yang H, Ju B, Lin YC, Keenan G, Price J, Landers CJ, Adams JS \& Targan SR. (2006) Treatment with infliximab is associated with increased markers of bone synthesis in patients with Crohn's disease. Journal of Clinical Gastroenterology. Vol.40, No.1, (January, 2006), pp. 55-63, ISSN 0192-0790

Ardizzone S \& Porro GB. (2005). Biologic therapy for inflammatory bowel disease. Drugs. Vol.65, No.16, pp. 2253-2286

Bickston SJ \& Muniyappa K. (2010). Natalizumab for the treatment of Crohn's disease. Expert Review of Clinical Immunology. Vol.6, No.4, (July, 2010), pp. 513-519, ISSN 1744-8409 
Cassinotti A, Ardizzone S \& Porro GB. (2008). Adalimumab for the treatment of Crohn's disease. Biologics: Targets \& Therapy. Vol.2, No.4, (December, 2008), pp. 763-777, ISSN 1177-5491

Dharmani P \& Chadee K. (2008). Biologic therapies against inflammatory bowel disease: a dysregulated immune system and the cross talk with gastrointestinal mucosa hold the key. Current Molecular Pharmacology. Vol.1, No.3, (November, 2008), pp. 195-212, ISSN 1874-4702

Hanauer SB, Feagan BG, Lichtenstein GR, Mayer LF, Schreiber S, Colombel JF, Rachmilewitz D, Wolf DC, Olson A, Bao W \& Rutgeerts P. (2002). Maintenance infliximab for Crohn's disease: the ACCENT I randomized trial. Lancet. Vol.359, No.9317, (May, 2002), pp. 1541-1549, ISSN 1474-547X

Hanauer SB, Sandborn WJ, Rutgeerts P, Fodorak RN, Lukas M, MacIntosh D, Panaccione R, Wolf D \& Pollack P. (2006). Human anti-tumor necrosis factor monoclonal antibody (adalimumab) in Crohn's disease: the CLASSIC-I trial. Gastroenterology. Vol.130, No.2, (February, 2006), pp. 323-333, ISSN 0016-5085

Lichtenstein GR. (2011) Crohn's disease: the complete guide to medical management. SLACK Incorporated. ISBN 978-1-55642-944-6, Thorofare, NJ, USA.

Mannon PJ, Fuss IJ, Mayer L, Elson CO, Sandborn WJ, Present D, Dolin B, Goodman N, Groden C, Hornung RL, Quezado M, Yang Z, Neurath MF, Salfeld J, Veldman GM, Schwertschlag U \& Strober W. (2004). Anti-interleukin-12 antibody for active Crohn's disease. The New England Journal of Medicine. Vol.352, No.20, (November, 2004), pp. 21-31, ISSN 1533-4406

Nielsen OH, Seidelin JB, Munck LK \& Rogler G. (2011). Use of biological molecules in the treatment of inflammatory bowel disease. Journal of Internal Medicine. Vol.270, No.1, (July, 2011), pp. 15-28, ISSN 1365-2796

Peyrin-Biroulet L, Deltenre P, Suray ND, et al. Efficacy and safety of tumor necrosis factor antagonists in Crohn's disease: meta-analysis of placebo-controlled trials. Clinical Gastroenterology \& Hepatology. Vol. 6, No.6, (June 2008): pp. 644-653. ISSN 1542-3565

Present DH, Rutgeerts P, Targan S, Hanauer SB, Mayer L, van Hogezand RA, Podolsky DK, Sands BE, Braakman T, Dewoody KL, Schaible TF, \& van Deventer SJ. (1999). Infliximab for the treatment of fistulas in patients with Crohn's disease. The New England Journal of Medicine. Vol.340, No.18, (May, 1999), pp. 1398-1405, ISSN 15334406

Recart E, Panaccione R, Loftus E, Tremaine W \& Sandborn W. (2001). Infliximab for Crohn's disease in clinical practice at the Mayo Clinic: the first 100 patients. The American Journal of Gastroenterology. Vol. 86, No.3, (March, 2001), pp. 722-729, ISSN 0002-9270

Reinisch W, Villier W, Bene L, Silmon L, Racz I, Katz S, Altorjay I, Feagan B, Riff D, Bernstein CN, Hommes D, Rutgeerts P, Cortot A, Gaspari M, Cheng M, Pearce T \& Sands BE. (2010). Fontolizumab in moderate to severe Crohn's disease: a phase 2, randomized, double-blind, placebo-controlled, multiple-dose study. Inflammatory Bowel Disease. Vol.16, No.2, (February, 2010), pp. 233-242 ISSN 1536-4844

Rutgeerts P, D'Haens G, Targan S, Vasiliauskas E, Haunauer SB, Present DH, Mayer L, Van Hogezand RA, Braakman T, Dewoody KL, Schaible TF \& van Deventer SJ. (1999). Efficacy and safety of retreatment with anti-tumor necrosis factor antibody (infliximab) to maintain remission in Crohn's disease. Gastroenterology. Vol.117, No.4, (October, 1999), pp. 761-769, ISSN 0016-5085 
Sandborn WJ, Feagan BG, Radford-Smith G, Kovacs A, Innes A \& Patel J. (2004). CDP571, a humanised monoclonal antibody to tumour necrosis factor $a$, for moderate to severe Crohn's disease: a randomised, double blind, placebo controlled trial. Gut. Vol.53, No.10, (October, 2004), pp. 1485-1493, ISSN 1468-3288

Sandborn WJ, Colombel JF, Enns R, Feagan B, Hananer S, Lawrance I, Panaccione R, Sanders M, Schreiber S, Targan S, Deventer SV \& Rutgeerts P. (2004). A phase III, double blind, placebo-controlled study of the efficacy, safety, and tolerability of antegren (Natalizumab) in maintaining clinical response and remission in Crohn's disease (ENACT-2). (Abstract). Gastroenterology. Vol.127, No.1, (July, 2004), pp. 332, ISSN 0016-5085

Sandborn WJ, Colombel JF, Enns R, Feagan B, Hanauer S, Lawrance IC, Panaccione R, Sanders M, Schreiber S, Targan S, Deventer SV, Goldblum R, Despain D, Hogge GS \& Rutgeerts P. (2005). Natalizumab induction and maintenance therapy for Crohn's disease. The New England Journal of Medicine. Vol.353, No.3, (November, 2005), pp. 1912-1925, ISSN 1533-4406

Sandborn WJ, Hanauer SB, Rutgeerts P, Fedorak RN, Lukas M, Maclntosh DG, Panaccione R, Wolf D, Kent JD, Bittle B, Li J \& Pollack PF. (2007). Adalimumab for maintenance treatment of Crohn's disease: results of the CLASSIC II trial. Gut. Vol.56, No.9, (September, 2007), pp. 1232-1239, ISSN 1468-3288

Sandborn WJ, Feagan BG, Stoinov S, Honiball PJ, Rutgeerts P, Mason D, Bloomfield R \& Schreiber S. (2007). Certolizumab pegol for the treatment of Crohn's disease. The New England Journal of Medicine. Vol.357, No.19, (July, 2007), pp. 228-238, ISSN 15334406

Sands BE, Van Deventer S, Bernstein C, et al. (2002). Long-term treatment of fistulizing Crohn's disease: response to infliximab in the ACCENT II trial through 54 weeks. Gastroenterology. Vol.122, supplement 4, (April, 2002), pp. A81, ISSN 0016-5085

Schreiber S, Khaliq-Kareemi M, Lawrance IC, Gazelle GS, Sands BE, Thomsen OO, Hanauer SB, McColm J Bloomfield R \& Sandborn WJ. (2007). Maintenance therapy with certolizumab pegol for Crohn's disease. The New England Journal of Medicine. Vol.357, No.19, (July, 2007), pp. 239-250, ISSN 1533-4406

Siegel CA, Hur C, Korzenik JR, Gazelle GS \& Sands BE. (2006). Risks and benefits of infliximab for the treatment of Crohn's disease. Clinical Gastroenterology and Hepatology. Vol.4, No.8, (August, 2006), pp. 1017-1024, ISSN 1542-3565

Targan SR, Haunauer SB, van Deventer SJH, Mayer L, Present DH, Braakman J, Dewoody KL, Schaible TF\& Rutgeerts PJ. (1997). A short-term study of chimeric monoclonal antibody cA2 to tumor necrosis factor $\alpha$ for Crohn's disease. The New England Journal of Medicine. Vol.337, No9, (October, 1997), pp. 1029-1035, ISSN 1533-4406 


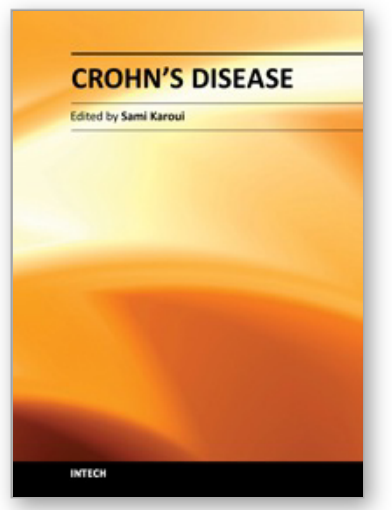

\author{
Crohn's Disease \\ Edited by Dr. Sami Karoui
}

ISBN 978-953-307-811-3

Hard cover, 210 pages

Publisher InTech

Published online 13, January, 2012

Published in print edition January, 2012

In this book, several important points regarding Crohn's disease are discussed. In the first section, we focus on etiopathogeny of Crohn's disease and the recent advances in our overall understanding of the disease specifically, the role of the gut epithelium, alterations of the epithelial crypts, and the roles of the different cytokines in the pathophysiology of Crohn's disease. In the second section, a diagnosis of Crohn's disease is discussed. Another particular area of focus is in the diagnosis of intestinal tuberculosis, and the role of mycobacterium avium in Crohn's disease. In the third and final section, the management of Crohn's disease is discussed, with a focus on recent evidence-based medicine recommendations.

\title{
How to reference
}

In order to correctly reference this scholarly work, feel free to copy and paste the following:

Shiyao Chen and Yuan Zhao (2012). Evidence-Based Evaluation of Biological Treatment in Crohn's Disease, Crohn's Disease, Dr. Sami Karoui (Ed.), ISBN: 978-953-307-811-3, InTech, Available from: http://www.intechopen.com/books/crohn-s-disease/evidence-based-evaluation-of-biological-treatment-incrohn-s-disease

\section{INTECH}

open science | open minds

\section{InTech Europe}

University Campus STeP Ri Slavka Krautzeka 83/A 51000 Rijeka, Croatia Phone: +385 (51) 770447

Fax: +385 (51) 686166 www.intechopen.com

\section{InTech China}

Unit 405, Office Block, Hotel Equatorial Shanghai No.65, Yan An Road (West), Shanghai, 200040, China 中国上海市延安西路65号上海国际贵都大饭店办公楼405单元 Phone: +86-21-62489820

Fax: +86-21-62489821 
(C) 2012 The Author(s). Licensee IntechOpen. This is an open access article distributed under the terms of the Creative Commons Attribution 3.0 License, which permits unrestricted use, distribution, and reproduction in any medium, provided the original work is properly cited. 